\title{
ПРООКСИДАНТНО-АНТИОКСИДАНТНИЙ БАЛАНС В ОРГАНІЗМІ ЩУРІВ НА ТЛІ СУБХРОНІЧНОЇ ДОКСОРУБЩИНОВОЇ ТОКСИЧНОСТІ ТА ЗАСТОСУВАННЯ ЕНТЕРОСОРБЦІЇ І ФІЛГРАСТИМУ (огляд літератури та результати власних досліджень)
}

\footnotetext{
Вступ. Антрациклінові антибіотики залишаються одними з найбільш затребуваних протипухлинних лікарських засобів завдяки високій цитотоксичній та протипухлинній активності. Однак протягом багатьох років невирішеною проблемою залишається їх кардіотоксичність та здатність викликати незворотне ушкодження міокарда з розвитком застійної серцевої недостатності з високою летальністю.

Мета дослідження - вивчити вплив ентеральної сорбційної терапії та препарату гранулоцитарного колонієстимулювального фрактора на показники прооксидантно-антиоксидантної рівноваги в щурів на моделі субхронічної токсичності доксорубіцину.

Методи дослідження. Експерименти проводили на статевозрілих щурах-самцях, в яких моделювали субхронічну доксорубіцинову токсичність, а для корекції застосовували гранульований вуглецевий ентеросорбент С2 самостійно та в комбінації з фрілграстимом. Досліджували показники ТБК-активних продуктів, активність каталази, супероксиддисмутази, вміст відновленого глутатіону в тканинах серця, печінки і сироватці крові, загальну антиокиснювальну активність сироватки крові.

Результати й обговорення. На тлі субхронічної доксорубіцинової токсичності в щурів виявлено порушення прооксидантно-антиоксидантного балансу, яке проявлялося зростанням рівня ТБК-активних продуктів у сироватці крові (у 2,07 раза), тканинах серця (у 2,3 раза) та печінки (в 1,7 раза). Одночасно спостерігали пригнічення ланок ендогенного антиоксидантного захисту зі зниженням активності каталази, супероксиддисмутази, вмісту відновленого глутатіону в усіх досліджуваних біологічних середовищах, яке було максимальним переважно в тканинах серця. Застосування ентеросорбенту С2 сприяло відновленню окисно-відновного балансу. Додаткове використання фрілграстиму продемонструвало подальше покращення досліджуваних показників і статистично достовірно переважало монозастосування ентеросорбенту за рівнем ТБК-активних продуктів у тканинах серця та активністю каталази в тканинах серця і сироватці крові.

Висновок. Отримані результати - підґрунтя для подальшого вивчення можливостей комбінованого застосування ентеральної сорбційної терапії та фрілграстиму з метою зменшення побічних ефектів антрациклінових антибіотиків.
}

КЛЮЧОВІ СЛОВА: прооксидантно-антиоксидантний баланс; доксорубіцин; ентеросорбція; фрілграстим; щури.

ВСТУП. Антрациклінові антибіотики залишаються одними 3 найбільш затребуваних протипухлинних лікарських засобів завдяки високій цитотоксичній та протипухлинній активності [1, 2]. Окрім типових для антинеопластичних препаратів побічних реакцій, таких, як нудота і блювання, ураження шлунково-кишкового тракту, гонадотоксичність, мієлодепресія та ін., вони здатні ушкоджувати серцевий м'яз. Їх кардіотоксичність із незворотним ушкодженням міо-

() О. О. Шевчук, А. С. Вольська, О. З. Яремчук, Х. І. Курило, К. І. Бардахівська, В. Г. Ніколаєв, К. А. Посохова, 2019. карда та розвитком застійної серцевої недостатності з високою летальністю впродовж багатьох років залишається невирішеною проблемою [1, $3,4]$. Ураження серця антрациклінами довгий час перебігає безсимптомно, прояви можуть маніфестувати через багато років після закінчення протипухлинної терапії, характеризуються труднощами в діагностиці [5]. Йдеться про достатньо значне число дітей і підлітків, які мали те чи інше злоякісне захворювання та отримували схеми поліхіміотерапії, що включали антрацикліни, а особливо доксорубіцин [6]. Єдиним 
лікарським засобом, серед показань до використання якого виділяють попередження кардіотоксичних проявів антрациклінів та ураження тканин при їх екстравазації, є дексразозан (кардіоксан) [7, 8]. Препарат достовірно зменшує прояви розвитку ураження серцевого м'яза (1 \% у групі хворих, які отримували дексразозан, проти 11 \% в осіб, яким його не призначали), однак не має позитивного впливу на безрецидивну та загальну виживаність пацієнтів [8].

Сучасні схеми та клінічні протоколи лікування серцевої недостатності включають лікарські засоби з різних фрармакологічних груп. Інгібітори ангіотензиноперетворювального фрерменту, антагоністи рецепторів ангіотензину II, бета-адреноблокатори, блокатори мінералокортикоїдних рецепторів, інгібітори неприлізину забезпечують клінічне покращення в майже 40 \% пацієнтів з дилатаційною кардіоміопатією, хворих із серцевою недостатністю із систолічною дисфрункцією, що супроводжується збільшенням фрракції викиду та поліпшенням геометрії серця [9-11]. Однак, як довели проведені клінічні випробування TRED-HF trial, ідеться про ремісію, але аж ніяк не про зворотний розвиток патології [12]. У всіх пацієнтів, які припинили лікування, протягом 8-ми тижнів відновилися всі прояви прогресуючої серцевої недостатності зі зниженням фрракції викиду >10 \% (менше 50 \%), зростанням кінцево-діастолічного тиску та високими цифррами NT-pro-BNP - >400 нг/л (при вихідному рівні 250 нг/л). У результаті всі учасники дослідження відновили приймання ліків.

Ще одним перспективним методом лікування серцевої недостатності зі зниженою фракцією викиду може бути трансплантація мезенхімальних стовбурових клітин, отриманих з пуповинної крові або кісткового мозку. Однак 2-га фраза клінічних випробувань не продемонструвала жодних переваг практично за всіма досліджуваними параметрами [13]. Ліковані та контрольні групи не відрізнялися за однорічними показниками смертності (14 та 15 \%) або ремісії (0,68 і 0,75/100 пацієнт-місяців). Єдине, що частота серйозних кровотеч за півроку спостереження була нижчою у групі пацієнтів, які отримували мезенхімальні стовбурові клітини (17 проти 33 \%), що повторювало висновки попереднього дослідження. Тож питання лікарських засобів та методів есрективної репарації кардіоміоцитів залишається відкритим.

Результати експериментів на моделях із серцевою недостатністю довели, що оксидативний стрес $є$ перспективною мішенню для лікування серцевої недостатності в людей, оскільки відіграє важливу роль у розвитку ушкодження серцевого м'яза і серцевої недостатності, дила- таційної кардіоміопатії та ураження кардіоміоцитів антрацикліновими антибіотиками. Боротьбу з оксидативним стресом можна вести в кількох напрямках, таких, як: пригнічення утворення прооксидантних речовин, збільшення активності та рівня ендогенного антиоксидантного захисту і призначення екзогенних антиоксидантів - вітамінів C, А, фролієвої кислоти тощо. На сьогодні вже $є$ результати деяких клінічних випробувань есрективності антиоксидантів. Досліджували есректи пригнічення ксантиноксидази в пацієнтів із хронічною серцевою недостатністю. Однак було отримано контроверсійні результати: в одних випадках призначення алопуринолу чи оксипуринолу (інгібіторів оксидативного стресу) мало позитивні ефректи на стан фрункції міокарда, ендотеліальну диссрункцію та супроводжувалося зниженням рівня натрійуретичного пептиду і підвищенням фрракції викиду, тоді як під час інших клінічних випробувань таких ефектів не спостерігали $[14,15]$. Деякі дослідження сорокусувалися на вивченні впливу екзогенного застосування вітамінів-антиоксидантів. Однак, незважаючи на значний ентузіазм дослідників із цього приводу, мета-аналіз 50-ти рандомізованих клінічних досліджень, які включали майже 300000 пацієнтів, не продемонстрував їх ефективності: зниження кардіоваскулярних ризиків було відсутнє [16]. ще покладаються певні надії на використання відновленого глутатіону та NAD+ [17]. Застосування донатора сульфгідрильних груп - N-ацетилцистеїну може давати позитивні результати, однак потребує подальшого вивчення. Деякі клінічні дослідження продемонстрували ефективність статинів, серед яких - розувастатину [18].

Наші попередні дослідження із цисплатиною та мелфаланом засвідчили виражений антиоксидативний ефект ентеральної сорбційної терапії з ентеросорбентом C2 $[19,20]$. Беручи до уваги те, що одним 3 механізмів дії антрациклінів $€$ генерація активних форм оксигену, запуск вільнорадикальних реакцій і активація оксидативного стресу, доцільно дослідити можливості ентеросорбції при доксорубіциновій субхронічній токсичності - класичній експериментальній моделі серцевої недостатності [21]. Відомо, що серед типових побічних ефектів протипухлинної поліхіміотерапії через пригнічення функції кісткового мозку дуже часто розвивається мієлодепресія [22, 23]. Препарати гранулоцитарного колонієстимулювального фрактора - засоби вибору в таких випадках [24, 25]. У деяких дослідженнях звертається увага на їх кардіопротекторні властивості при застосуванні доксорубіцину в щурів [26, 27].

Отже, преклінічні дослідження на тваринах демонструють переваги засобів, що зменшують 
оксидативний стрес, які, однак, не завжди спостерігають при виконанні клінічних випробувань. Це означає, що необхідний пошук нових засобів та стратегій боротьби з оксидативним стресом при проведенні протипухлинної хіміотерапії.

Мета дослідження - вивчити вплив ентеральної сорбційної терапії та препарату гранулоцитарного колонієстимулювального фрактора на показники прооксидантно-антиоксидантної рівноваги в щурів на моделі субхронічної токсичності доксорубіцину.

МЕТОДИ ДОСЛІДЖЕННЯ. Експерименти проводили на статевозрілих інбредних щурах-

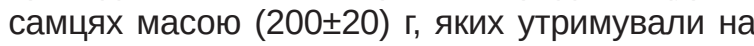
стандартному раціоні віварію Тернопільського національного медичного університету імені І. Я. Горбачевського МОЗ України з доступом ad libitum до питної води. Тварин шляхом сліпої вибірки було рандомізовано в такі групи $(\mathrm{n}=10)$ : 1-ша - контрольна (здорові щури); 2-га - тварини, які отримували доксорубіцин (DOX); 3-тя щури, які з метою корекції одержували ентеральну сорбційну терапію з гранульованим вуглецевим ентеросорбентом C2 (DOX+C2); 4-та - тварини, які для корекції отримували ентеральну сорбційну терапію та препарат гранулоцитарного колонієстимулювального фрактора фрілграстим (DOX+C2+фрілграстим).

Усі маніпуляції проводили 3 дотриманням принципів біоетики відповідно до положення Європейської конвенції про захист хребетних тварин, що використовуються для дослідних та інших наукових цілей (European convention for the protection of vertebrate animals used for experimental and other scientific purposes, Страсбург, 1986), Закону України “Про захист тварин від жорстокого поводження" (№ 1759-VI від 15.12.2009р.) та Директиви Європейського Союзу 2010/10/63 EU щодо експериментів на тваринах.

Субхронічну токсичність доксорубіцину моделювали шляхом введення препарату (Doxorubicin Teva, 10 мг/5 мл, TEVAPharmachemie, the Netherlands) внутрішньочеревно 1 раз на тиждень 3 розрахунку 5 мг/кг маси щура чотирикратно (кумулятивна доза - 20 мг/кг маси тіла) [21]. Тварини контрольної групи отримували інтраперитонеально еквівалентну кількість стерильного ізотонічного фрізрозчину.

Вуглецевий гранульований ентеросорбент C2 (насипна маса - 0,18 г/см³ ${ }^{3}$ розмір гранул 0,15-0,25 мм, площа пор за ВЕТ - 2162 м²/г) вводили внутрішньошлунково у вигляді зависі в дистильованій воді за допомогою зонда, починаючи з наступного дня після ін'єкції доксорубіцину, з розрахунку 5 мл на 1000 г маси щура, що становило 900 мг/кг сухої маси. Тварини кон- трольної групи отримували еквівалентну кількість дистильованої води. Філграстим - офріцинальний препарат гранулоцитарного колонієстимулювального фрактора (Нейпоген, F.HoffmannLa Roche Ltd.) - вводили підшкірно з розрахунку 50 мкг/кг, починаючи 3 наступного дня після четвертої ін'єкції доксорубіцину, впродовж 4-х днів 1 раз на добу.

На 29-ту добу після першої ін'єкції доксорубіцину тварин під загальним знеболюванням тіопентал-натрієм виводили з експерименту. Для досліджень брали сироватку крові, тканини серця та печінки. У гомогенатах тканин та сироватці крові піддослідних тварин визначали вторинні продукти вільнорадикального окиснення - рівень ТБК-активних продуктів (ТБК-АП) [28]; показники антиоксидантного захисту: активність супероксиддисмутази (СОД) [29], каталази (КАТ) [30], вміст відновленого глутатіону (G-SH) [31], загальну антиокиснювальну активність сироватки крові (3АА) [32].

Отриманий цифровий матеріал було оброблено методом варіаційної статистики з використанням непараметричних критеріїв та однофакторного дисперсійного аналізу (ANOVA). Для перевірки нормальності вибірок застосовували критерій Шапіро - Уїлка. Дані вказано як середні арифметичні величини (M) та їх похибки (SE). Зміни вважали достовірними при $p<0,05$. У таблицях рівень значимості вказували тільки для достовірних результатів. Для розрахунків використовували комп'ютерну програму StatSoft STATISTICA 10.

РЕЗУЛЬТАТИ Й ОБГОВОРЕННЯ. У ГРУП тварин, які отримували сумарну дозу доксорубіцину 20 мг/кг протягом 4-х тижнів, розвинувся виражений дисбаланс прооксидантно-антиоксидантної системи (табл. 1-3). Так, рівень вторинних продуктів пероксидного окиснення ліпідів (ТБК-активних продуктів) достовірно зростав у всіх досліджуваних середовищах: у сироватці крові - в 2,07 раза, у тканинах печінки - в 1,7 раза, у тканинах серця - в 2,3 раза.

Водночас активність СОД знижувалася: на 58,4 \% - у тканинах печінки, на 38,3 \% - у тканинах серця. Показники активності КАТ мали таку ж спрямованість: у сироватці крові були меншими на 32,5 \%, у тканинах печінки - на 28,8 \%, а в тканинах серця - на 33,5 \% порівняно з тваринами контрольної групи. Спостерігали чітку тенденцію до зниження ЗАА. Водночас вміст глутатіону на тлі субхронічної доксорубіцинової токсичності зменшувався: на 27,7 \%-у тканинах печінки, на 41,9 \% - у тканинах серця. Це свідчило про високу інтенсивність оксидативного стресу при застосуванні доксорубіцину. 
Таблиця 1 - Показники про-, антиоксидантної рівноваги в міокарді піддослідних тварин на тлі застосування доксорубіцину, ентеросорбенту C2 та фрілграстиму (M $\pm \mathrm{SE})$

\begin{tabular}{|c|c|c|c|c|}
\hline \multirow{2}{*}{ Показник } & \multicolumn{4}{|c|}{ Група тварин } \\
\hline & контрольна & DOX & $\mathrm{DOX}+\mathrm{C} 2$ & DOX+C2+срілграстим \\
\hline ТБК-АП, мКМОЛЬ/кГ & $6,59 \pm 0,11$ & $14,95 \pm 1,57^{\star}$ & $9,24 \pm 0,55^{\star, \star \star}$ & $7,23 \pm 0,47^{\star \star, \#}$ \\
\hline KAT, кат/кг & $4,04 \pm 0,46$ & $2,69 \pm 2,49 *$ & $3,57 \pm 0,22$ ** & $4,15 \pm 4,32^{\star \star}$ \\
\hline СОД, ум. од./кг & $2,58 \pm 0,27$ & $1,59 \pm 0,11^{*}$ & $1,82 \pm 0,11^{\star \star}$ & $1,97 \pm 0,21^{\star, \star \star, \#}$ \\
\hline G-SH, ммоль/кг & $1,57 \pm 0,22$ & $0,91 \pm 0,18^{*}$ & $1,38 \pm 0,09 * \star$ & $1,37 \pm 0,07^{\star \star}$ \\
\hline
\end{tabular}

Примітки. Тут і в таблицях 2, 3 достовірність р<0,05 відносно: * - інтактних тварин; ** - тварин, які отримували доксорубіцин; \# - тварин, які, крім доксорубіцину, одержували сорбент С2.

Таблиця 2 - Показники про-, антиоксидантної рівноваги в сироватці крові піддослідних тварин на тлі застосування доксорубіцину, ентеросорбенту C2 та фрілграстиму (M $\pm \mathrm{SE})$

\begin{tabular}{|l|c|c|c|c|}
\hline \multirow{2}{*}{\multicolumn{1}{|c|}{ Показник }} & \multicolumn{3}{|c|}{ Група тварин } \\
\cline { 2 - 5 } & контрольна & DOX & DOX+C2 & DOX+C2+срілграстим \\
\hline ТБК-АП, мкмоль/л & $0,37 \pm 0,05$ & $0,76 \pm 0,06^{*}$ & $0,54 \pm 0,06^{\star \star}$ & $0,53 \pm 0,05^{\star \star}$ \\
\hline КАТ, кат/л & $5,85 \pm 0,31$ & $3,94 \pm 0,62^{*}$ & $4,87 \pm 0,42^{*},{ }^{* *}$ & $4,92 \pm 0,41^{*},{ }^{* *}$, \\
\hline ЗАА, \% & $50,97 \pm 2,12$ & $37,92 \pm 2,77$ & $44,92 \pm 2,14$ & $45,92 \pm 1,89$ \\
\hline
\end{tabular}

Таблиця 3 - Показники про-, антиоксидантної рівноваги в тканинах печінки піддослідних тварин

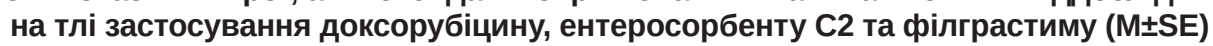

\begin{tabular}{|c|c|c|c|c|}
\hline \multirow{2}{*}{ Показник } & \multicolumn{4}{|c|}{ Група крові } \\
\hline & контрольна & DOX & $\mathrm{DOX}+\mathrm{C} 2$ & DOX+C2+opiлграстим \\
\hline ТБК-АП, мКМОЛЬ/кг & $6,92 \pm 0,13$ & $11,88 \pm 0,24^{*}$ & $8,79 \pm 0,62^{\star}$, ,* & $7,79 \pm 0,39^{\star *}$ \\
\hline КАТ, кат/кг & $6,80 \pm 0,33$ & $4,84 \pm 0,59 *$ & $6,57 \pm 0,64^{*}$,** & $6,66 \pm 0,39$ ** \\
\hline СОД, ум. од./кг & $5,72 \pm 0,33$ & $2,38 \pm 0,25^{\star}$ & $3,52 \pm 0,34^{*}, * *$ & $3,85 \pm 0,21^{*}, * *$ \\
\hline G-SH, ммоль/кг & $2,32 \pm 0,12$ & $1,67 \pm 0,07^{*}$ & $1,90 \pm 0,09^{*}$ & $1,87 \pm 0,07^{\star}$ \\
\hline
\end{tabular}

Застосування ентеральної сорбційної терапії $з$ вуглецевим гранульованим ентеросорбентом С2 сприяло зниженню інтенсивності процесів оксидації та незначному відновленню балансу в прооксидантно-антиоксидантній системі. Спостерігали зменшення рівня ТБК-активних продуктів на 28,6, 26,0 і 38,2 \%, відповідно, у сироватці крові, тканинах печінки та серця порівняно зі щурами групи DOX. Ці дані узгоджуються з отриманими раніше результатами і роботами інших авторів [23, 33-36].

щодо ключових ендогенних ензимів антиоксидантного захисту, то активність СОД у тканинах печінки зростала на 47,9 \%, у тканинах серця - лише на 14,5 \%; активність КАТ - на 35,8 та 32,9 \% відповідно. У сироватці крові активність KAT підвищувалася на 23,4 \% у групі DOX+C2 порівняно з групою DOX. Під впливом сорбційної ентеральної терапії вміст глутатіону в серці збільшувався на 51,2 \%, та спостерігали чітку тенденцію до його зростання в печінці.

Додаткове використання фрілграстиму до курсу ентеросорбції сприяло подальшому позитивному прогресуванню досліджуваних показників, однак не перевищувало за більшістю показників монозастосування ентеросорбенту С2. Рівень ТБК-АП під впливом комбінації чинників знижувався: на 29,9 \% - у сироватці крові, на 34,4 \% - у тканинах печінки та на 51,6 \% - у тканинах серця. Останній показник достовірно відрізнявся від такого в групі тварин, які на тлі введення доксорубіцину отримували лише ентеросорбент, - на 21,7 \%. Активність СОД у цих щурів зростала: на 67,1 \% - у тканинах печінки, на 23,5 \% - у тканинах серця. Показник активності КАТ у тканинах печінки був вищим на $37,6 \%$, а в тканинах серця - на 54,3 \%. Щодо активності каталази в сироватці крові спостерігали тенденцію до її нормалізації. Усі вказані показники мали тенденцію до покращення порівняно з групою тварин DOX+C2, так само, як і ЗАА. Вміст глутатіону в тканинах серця тварин групи DOX+C2 зростав на 50,2 \% при дії обох чинників корекції та не відрізнявся від показника щурів групи DOX.

Оксидативний стрес, який є частиною патогенезу багатьох хронічних патологічних станів та захворювань, включаючи серцеву недостатність, розвивається внаслідок дисбалансу між продукуванням вільних радикалів та здатністю організму до антиоксидантного захисту [37]. Гіперпродукування первинних та вторинних продуктів надмірного окиснення протеїнів, ліпідів і ДНК призводить до ушкодження клітин та індукує процеси апоптозу і некрозу. Це стосується і пацієнтів із хронічною серцевою недостатністю, в яких спостерігають розвиток оксидативного стресу та пригнічення механізмів і ланок анти- 
оксидантного захисту. Компонентами захисту кардіоміоцитів є супероксиддисмутаза, каталаза, нікотинамід динуклеотид, глутатіонпероксидаза та відновлений глутатіон. Дослідження на тваринах продемонстрували зниження активності супероксиддисмутази, каталази та глутатіонпероксидази на експериментальних постінфрарктних моделях серцевої недостатності $[38,39]$ Більше того, надмірна кількість вільних радикалів стимулює проліфрерацію міокардіальних фрібробластів та ремоделювання камер серця. Ці дані узгоджуються з результатами, які ми отримали. Цитотоксичні ефекти доксорубіцину пов'язані з утворенням активних форм оксигену в результаті редокс-циклічних реакцій та впливу препарату на обмін заліза [40]. Усе це призводить до виснаження запасів відновленого глутатіону, зменшення внутрішньоклітинного окисно-відновного потенціалу і через ряд сигнальних клітинних месенджерів запускає програму апоптозу.

Відомо, що міокард має обмежений потенціал для регенерації та проліферації, адже кардіоміоцити є високоспеціалізованими і високодиференційованими клітинами. Окрім того, в серцевому м'язі низький рівень ендогенних ензимів антиоксидантів, таких, як каталаза і супероксиддисмутаза, тобто низький потенціал для боротьби з оксидативним стресом, що надзвичайно важливо як для патогенезу серцево-судинної патології, так і для реалізації побічної дії протипухлинних лікарських засобів [41].

Використання ентеральної сорбційної терапії з ентеросорбентом С2 сприяло відновленню окисно-відновного балансу: знижувався рівень продуктів надмірної ліпопероксидації і зростали активність ензимів антиоксидантного захисту та вміст глутатіону. Комбінація С2 з фрілграстимом на тлі субхронічної доксорубіцинової токсичності достовірно переважала монозастосування ентеросорбції за показниками ТБК-активних продуктів у тканинах серця та активністю каталази в тканинах серця і сироватці крові.

Основною вимогою, яку висувають до засобів терапії супроводу в онкології, $€$ те, що вони повинні знижувати токсичність цитостатичної терапії, не ушкоджувати нормальних здорових клітин організму та не знижувати (в ідеалі навіть посилювати) протипухлинного ефекту лікування $[42,43]$. Щоб уникнути будь-якої взаємодії між досліджуваними препаратами (ентеросорбентом, доксорубіцином та срілграстимом) і будьякого впливу на фрармакокінетичні параметри та фармакодинаміку препарату, ми за добу до наступного введення цитостатика і в день введен- ня сорбенту не застосовували. Доксорубіцин метаболізується печінкою [44]. К. Nagai та ін. довели, що концентрація препарату в крові після інтраперитонеального введення швидко досягає піку і зменшується подібно до внутрішньовенного застосування [45]. Елімінація доксорубіцину з плазми крові двофразна з періодом напіввиведення 15-30 хв на початковому етапі та 16,5 год у термінальну фразу. Враховуючи схему введення ентеросорбенту, яку ми запропонували, можемо повністю виключити вплив ентеросорбції на фрармакокінетику та цитотоксичність антрациклінового антибіотика.

ВИСНОВКИ. 1. У щурів виявлено порушення прооксидантно-антиоксидантного балансу на тлі субхронічної доксорубіцинової токсичності (сумарна доза препарату становила 20 мг/кг протягом 4-х тижнів), яке проявлялося зростанням рівня ТБК-активних продуктів у сироватці крові (в 2,07 раза), тканинах серця (в 2,3 раза) та печінки (в 1,7 раза). Одночасно спостерігали пригнічення ланок ендогенного антиоксидантного захисту зі зниженням активності каталази, супероксиддисмутази і вмісту відновленого глутатіону в усіх досліджуваних біологічних середовищах, яке було максимальним переважно в тканинах серця.

2. Застосування ентеральної сорбційної терапії з ентеросорбентом С2 сприяло відновленню окисно-відновного балансу: знижувався рівень ТБК-активних продуктів - на 28,6, 26,0 і 38,2 \% у сироватці крові, тканинах печінки та серця. Водночас зростали активність ензимів антиоксидантного захисту та вміст глутатіону. Активність супероксиддисмутази в тканинах печінки підвищувалась на 47,9 \%, у тканинах серця - лише на 14,5\%; активність каталази - на 35,8 та 32,9 \% відповідно; вміст глутатіону в тканинах серця збільшувався на 51,2 \%.

3. Додаткове застосування фрілграстиму до курсу ентеросорбції на тлі субхронічної доксорубіцинової токсичності сприяло подальшому покращенню досліджуваних показників та достовірно переважало монозастосування С2 за рівнем ТБК-активних продуктів у тканинах серця та активністю каталази в тканинах серця і сироватці крові.

4. Отримані результати - підґрунтя для подальшого вивчення можливостей застосування ентеральної сорбційної терапії та фрілграстиму з метою зменшення побічних ефектів антрациклінових антибіотиків. 


\section{СПИСОК ЛІТЕРАТУРИ}

1. State of the art review: Chemotherapy-induced cardiotoxicity in children / R. W. Loar, C. Noel, H. Tunuguntla [et al.] // Congenital Heart Disease. -2018. -13, No. 1. - P. 5-15.

2. Doxorubicin pathways: pharmacodynamics and adverse effects / C. F. Thorn, C. Oshiro, S. Marsh, [et al.] // Pharmacogenetics and Genomics. -2011. -21, No. 7. P. 440-446.

3. Doxorubicin cardiomyopathy / K. Chatterjee, J. Zhang, N. Honbo [et al.] // Cardiology. - 2010. - 115, No. 2. - P. 155-162.

4. Cardiotoxicity of anticancer treatments: Epidemiology, detection, and management / G. Curigliano, D. Cardinale, S. Dent [et al.] // CA: A Cancer Journal for Clinicians. - 2016. - 66, No. 4. - P. 309-325.

5. Theoretical ground for adsorptive therapy of anthracyclines cardiotoxicity / O. O. Shevchuk, K. A. Posokhova, L. A. Sakhno [et al.] // Experimental Oncology. 2012. - 34, No. 4. - P. 314-322.

6. Mitry M. A. Doxorubicin induced heart failure: Phenotype and molecular mechanisms / M. A. Mitry, J. G. Edwards // Int. J. Cardiol. Hear. Vasc. - 2016. No. 10. - P. 17-24.

7. Assessment of dexrazoxane as a cardioprotectant in doxorubicin-treated children with high-risk acute lymphoblastic leukaemia: long-term follow-up of a prospective, randomised, multicentre trial / P. S. E. Lipshultz, R. E. Scully, S. R. Lipsitz [et al.] // The Lancet Oncology. - 2010. - 11, No. 10. - P. 950-961.

8. Langer S. W. Dexrazoxane for the treatment of chemotherapy-related side effects / S. W. Langer // Cancer Management and Research. - 2014. - 6. P. 357-363.

9. 2016 ACC/AHA/HFSA Focused Update on New Pharmacological Therapy for Heart Failure: An Update of the 2013 ACCF/AHA Guideline for the Management of Heart Failure: A Report of the American College of Cardiology/American Heart Association Task Force on Clinic / C. W. Yancy, M. Jessup, B. Bozkurt [et al.] // Circulation. - 2016. - 134, No. 13.

10. Nijst P. Heart failure with myocardial recovery the patient whose heart failure has improved: what next? / P. Nijst, P. Martens, W. Mullens // Progress in Cardiovascular Diseases. - 2017. - 60, No. 2. - P. 226-236.

11. Curfman G. Stem cell therapy for heart failure / G. Curfman // JAMA. - 2019. - 321, No. 12. - P. 1186.

12. Withdrawal of pharmacological treatment for heart failure in patients with recovered dilated cardiomyopathy (TRED-HF): an open-label, pilot, randomised trial / B. P. Halliday, R. Wassall, A. S. Lota [et al.] // The Lancet. - 2019. - 393, No. 10166. - P. 61-73.

13. Intramyocardial injection of mesenchymal precursor cells and successful temporary weaning from left ventricular assist device support in patients with advanced heart failure / T. M. Yau, F. D. Pagani, D. M. Mancini [et al.] // JAMA. - 2019. - 321, No. 12. - P. 1176.

14. Rationale, design and organisation of an efficacy and safety study of oxypurinol added to standard therapy in patients with NYHA class III - IV congestive heart failure / R. S. Freudenberger, R. P. Jr. Schwarz, J. Brown [et al.] // Expert Opinion on Investigational Drugs. 2004. - 13, No. 11. - P. 1509-1516.

15. Impact of oxypurinol in patients with symptomatic heart failure. Results of the OPT-CHF Study / J. M. Hare,
B. Mangal, J. Brown [et al.] // Journal of the American College of Cardiology. - 2008. - 51, No. 24. - P. $2301-$ 2309.

16. Vitamins in heart failure: Friend or enemy? / G. Georgiopoulos, C. Chrysohoou, G. Vogiatzi, [et al.] // Current Pharmaceutical Design. - 2017. - 23, No. 25. P. 3731-3742.

17. N-acetylcysteine attenuates the development of cardiac fibrosis and remodeling in a mouse model of heart failure / B. Giam, P. Y. Chu, S. Kuruppu [et al.] // Physiological Reports. - 2016. - 4 (7). - P. e12757.

18. Rosuvastatin protects against oxidative stress and DNA damage in vitro via upregulation of glutathione synthesis / N. Schupp, U. Schmid, A. Heidland [et al.] // Atherosclerosis. - 2008. - 199, No. 2. - P. 278-287.

19. Шевчук О. О. Вплив вуглецевого ентеросорбенту і гранулоцитарного колонієстимулюючого фрактора на проксидантно-антиоксидатний гомеостаз на тлі застосування мелфалану / О.О.Шевчук // Фармакологія та лікарська токсикологія. - 2015. - № 4-5. С. 97-102.

20. Enterosorption as a method to decrease the systemic toxicity of cisplatin / L. A. Sakhno, O. V. Yurchenko, V. N. Maslenniy [et al.] // Experimental Oncology. -2013 . -35 , No. 1. - P. 45-52.

21. Доклінічні дослідження лікарських засобів : метод. рек. / за ред. О. В. Стесранова. - К. : Авіцена, 2001. - 528 c.

22. Risk factors for chemotherapy-induced neutropenia occurrence in breast cancer patients: data from the INC-EU Prospective Observational European Neutropenia Study / M. Schwenkglenks, R. Pettengell, C. Jackisch [et al.] // Supportive care in Cancer: Official Journal of the Multinational Association of Supportive Care in Cancer. 2011. - 19, No. 4. - P. 483-490.

23. The influence of enterosorption on some haematological and biochemical indices of the normal rats after single injection of melphalan / O. O. Shevchuk, K. A. Posokhova, A. S. Sidorenko [et al.] // Experimental Oncology. - 2014. - 36, No. 2. - P. 94-100.

24. Бруслова К. М. Застосування препарату теваграстим у дітей з гострими лейкеміями / К. М. Бруслова // Онкологія. - 2013. - 15, № 1. - С. 51-54.

25. Крячок I. А. Використання гранулоцитарних колонієстимулюючих фракторів при проведенні протипухлинної терапії / І. А. Крячок, І. Б. Титоренко // Клинич. онкология. - 2015. - 19, № 3. - С. 64-68.

26. Hematopoietic cytokines for cardiac repair: mobilization of bone marrow cells and beyond / S. K. Sanganalmath, A. Abdel-Latif, R. Bolli [et al.] // Basic Research in Cardiology. - 2011. - 106, No. 5. - P. 709-733.

27. Granulocyte colony-stimulating factor reduces cardiomyocyte apoptosis and improves cardiac function in adriamycin-induced cardiomyopathy in rats / W. H. Xu, J. Son, Y. Wang [et al.] // Cardiovascular Drugs and Therapy. - 2006. - 20, No. 2. - P. 85-91.

28. Андреева Л. И. Модификация метода определения перекисей липидов в тесте с тиобарбитуровой кислотой / Л. И. Андреева, Л. А. Кожемякин, А. А. Кишкун // Лаб. дело. - 1988. - № 11. - С. 41-43.

29. Чевари С. Роль супероксиддисмутазы в окислительных процессах клетки и метод определения ее в биологических материалах / С. Чевари, И. Чаба, и. Секей // Лаб. дело. - 1985. - № 11. - С. 678-681. 
30. Метод определения активности каталазы / М. А. Королюк, Л. К. Иванова, И. Г. Майорова [и др.] // Клинич. лаб. диагностика. - 1988. - № 4. - С. 44-47.

31. Ellman G. L. Tissue sulfhydryl groups / G. L. Ellman // Archives of biochemistry and biophysics. 1959. - 82, No 1. - P. 70-77.

32. Assay using brain homogenate for measuring the antioxidant activity of biological fluids / J. Stocks J. M. C. Gutteridge, R. J. Sharp [et al.] // Clin. Sci. Mol. Med. - 1974. - 47. - P. 215-222.

33. Грек О. Р. Протективное действие энтеросгеля на лизосомы печени крыс при введении комплекса цитостатических препаратов / О. Р. Грек, С. В. Мишенина, А. Б. Пупышев // Бюлл. эксперим. биологии и медицины. - 2002. - 134, № 10. - С. 413-417.

34. Профрілактика за допомогою вуглецевого ентеросорбенту гострої та відстроченої еметогенної токсичності хіміотерапевтичного лікування онкологічних хворих / О.В.Пономарьова, В.М.Півнюк, М. М. Носко [та ін.] // Онкологія. - 2008. - 10, № 3. C. 370-373.

35. Посохова К. А. Корекція гепатотоксичної дії антиретровірусних засобів за допомогою глутаргіну та ентеросгелю / К. А. Посохова, О. О. Шевчук // Укр. журн. клініч. та лаб. медицини. - 2010. - 5, № 4. C. $130-133$.

36. Застосування препарату ентеросгель для просрілактики оксидативного стресу при гострій крововтраті / В. Г. Ніколаєв, І. М. Кліщ, І.В.Жулкевич [та ін.] // Вісн. наук. дослідж. - 2009. - № 1. - С. 72-74.

37. Lushchak V. I. Classification of oxidative stress based on its intensity / V. I. Lushchak // EXCLI Journal. 2014. - 13. - P. 922-937.

\section{REFERENCES}

1. Loar, R.W., Noel, C., Tunuguntla, H., Colquitt, J.L., \& Pignatelli, R.H. (2018). State of the art review: Chemotherapy-induced cardiotoxicity in children. Congenital Heart Disease, 13 (1), 5-15. Retrieved from: https://doi. org/10.1111/chd.12564

2. Thorn, C.F., Oshiro, C., Marsh, S., HernandezBoussard, T., McLeod, H., Klein, T.E., \& Altman, R.B. (2011). Doxorubicin pathways: pharmacodynamics and adverse effects. Pharmacogenetics and Genomics, 21 (7), 440-446. Retrieved from: https://doi.org/10.1097/ FPC.0b013e32833ffb56

3. Chatterjee, K., Zhang, J., Honbo, N., \& Karliner, J.S. (2010). Doxorubicin cardiomyopathy. Cardiology, 115 (2), 155-162. Retrieved from: https://doi.org/10.1159/ 000265166

4. Curigliano, G., Cardinale, D., Dent, S., Criscitiello, C., Aseyev, O., Lenihan, D., \& Cipolla, C.M. (2016). Cardiotoxicity of anticancer treatments: Epidemiology, detection, and management. CA: A Cancer Journal for Clinicians, 66 (4), 309-325. Retrieved from: https://doi. org/10.3322/caac.21341.

5. Shevchuk, O.O., Posokhova, E.A., Sakhno, L.A., \& Nikolaev, V.G. (2012). Theoretical ground for adsorptive therapy of anthracyclines cardiotoxicity. Experimental Oncology, 34 (4), 314-322.
38. Antioxidant enzyme gene expression in congestive heart failure following myocardial infarction / N. Khaper, K. Kaur, T. Li [et al.] // Molecular and Cellular Biochemistry. - 2003. - 251, No. 1-2. - P. 9-15.

39. Khaper N. Effects of afterload-reducing drugs on pathogenesis of antioxidant changes and congestive heart failure in rats / N. Khaper, P. K. Singal // Journal of the American College of Cardiology. - 1997. - 29, No. 4. P. 856-861.

40. Protective effects of aliskiren in doxorubicininduced acute cardiomyopathy in rats / A. Rashikh, Abul Kalam Najmi, M. Akhtar [et al.] // Human and Experimental Toxicology. - 2011. - 30, No. 2. - P. 102-109.

41. Перспективы использования антиоксидантов в профилактике кардиотоксичности, вызванной применением антрациклиновых антибиотиков / О. Ю. Голубцов, В. В. Тыренко, А. С. Поляков [и др.] // Вестн. Нац. медико-хирургического центра им. Н. И. Пирогова. - 2017. - № 2. - С. 121-125.

42. Коваленко В. Н. Поражение сердца цитостатиками / Н. В. Калинкина, Н. Т. Ватутин. - Донецк : УкрНТЭК, 2002. - 349 с.

43. Використання нових лікарських форм кверцетину для профрілактики доксорубіцинової кардіоміопатії в експерименті / В. Й. Мамчур, А. С. Шаламай, М. Г. Старченко [та ін.] // Мед. перспективи. - 2005. 10, № 4. - C. 4-8.

44. Yan T. D. A pharmacological review on intraperitoneal chemotherapy for peritoneal malignancy / T. D. Yan // World Journal of Gastrointestinal Oncology. 2010. - 2, No. 2. - P. 109-116.

45. Pharmacokinetic evaluation of intraperitoneal doxorubicin in rats / K. Nagai, S. Nogami, H. Egusa [et al.] // Pharmazie. - 2014. - 69. - P. 125-127.

6. Mitry, M.A., \& Edwards, J.G. (2016). Doxorubicin induced heart failure: Phenotype and molecular mechanisms. International Journal of Cardiology. Heart \& Vasculature, 10, 17-24. Retrieved from: https://doi. org/10.1016/j.ijcha.2015.11.004

7. Lipshultz, P.S.E., Scully, R.E., Lipsitz, S.R., Sallan, P.S.E., Silverman, L.B., Miller, P.T.L., ... Colan, P.S.D. (2010). Assessment of dexrazoxane as a cardioprotectant in doxorubicin-treated children with high-risk acute lymphoblastic leukaemia: long-term follow-up of a prospective, randomised, multicentre trial. The Lancet Oncology, 11 (10), 950. Retrieved from: https://doi. org/10.1016/S1470-2045(10)70204-7

8. Langer, S.W. (2014). Dexrazoxane for the treatment of chemotherapy-related side effects. Cancer Management and Research, 6, 357-363. Retrieved from: https://doi.org/10.2147/CMAR.S47238

9. Yancy, C.W., Jessup, M., Bozkurt, B., Butler, J., Casey, D.E., Colvin, M.M., ... Westlake, C. (2016). 2016 ACC/AHA/HFSA Focused Update on New Pharmacological Therapy for Heart Failure: An Update of the 2013 ACCF/AHA Guideline for the Management of Heart Failure: A Report of the American College of Cardiology/ American Heart Association Task Force on Clinic. Circulation, 134 (13). Retrieved from: https://doi.org/10.1161/ CIR.0000000000000435 
10. Nijst, P., Martens, P., \& Mullens, W. (2017). Heart failure with myocardial recovery - the patient whose heart failure has improved: What next? Progress in Cardiovascular Diseases, 60 (2), 226-236. Retrieved from: https:// doi.org/10.1016/j.pcad.2017.05.009

11. Curfman, G. (2019). Stem cell therapy for heart failure. JAMA, 321 (12), 1186. Retrieved from: https://doi. org/10.1001/jama.2019.2617

12. Halliday, B.P., Wassall, R., Lota, A. S., Khalique, Z., Gregson, J., Newsome, S., ... Prasad, S.K. (2019). Withdrawal of pharmacological treatment for heart failure in patients with recovered dilated cardiomyopathy (TREDHF): an open-label, pilot, randomised trial. The Lancet, 393 (10166), 61-73. Retrieved from: https://doi. org/10.1016/S0140-6736(18)32484-X

13. Yau, T.M., Pagani, F.D., Mancini, D.M., Chang, H.L., Lala, A., Woo, Y.J., ... Milano, C.A. (2019). Intramyocardial injection of mesenchymal precursor cells and successful temporary weaning from left ventricular assist device support in patients with advanced heart failure. JAMA, 321 (12), 1176. Retrieved from: https://doi. org/10.1001/jama.2019.2341.

14. Freudenberger, R.S., Schwarz Jr.,R.P., Brown, J., Moore, A., Mann, D., Givertz, M.M., ... Hare, J.M. (2004). Rationale, design and organisation of an efficacy and safety study of oxypurinol added to standard therapy in patients with NYHA class III - IV congestive heart failure. Expert Opinion on Investigational Drugs, 13 (11), 1509 1516. Retrieved from: https://doi.org/10.1517/13543784. 13.11.1509.

15. Hare, J.M., Mangal, B., Brown, J., Fisher, C., Freudenberger, R., Colucci, W. S., ... Schwarz, R.P. (2008). Impact of oxypurinol in patients with symptomatic heart failure. Results of the OPT-CHF Study. Journal of the American College of Cardiology, 51 (24), 2301-2309. Retrieved from: https://doi.org/10.1016/j.jacc.2008.01.068

16. Georgiopoulos, G., Chrysohoou, C., Vogiatzi, G., Magkas, N., Bournelis, I., Bampali, S., ... Tousoulis, D. (2017). Vitamins in heart failure: Friend or enemy? Current Pharmaceutical Design, 23 (25), 3731-3742. Retrieved from: https://doi.org/10.2174/138161282366617 0321094711.

17. Giam, B., Chu, P.Y., Kuruppu, S., Smith, A.I., Horlock, D., Kiriazis, H., ... \& Rajapakse, N.W. (2016). $\mathrm{N}$-acetylcysteine attenuates the development of cardiac fibrosis and remodeling in a mouse model of heart failure. Physiological Reports, 4 (7), e12757.

18. Schupp, N., Schmid, U., Heidland, A., \& Stopper, H. (2008). Rosuvastatin protects against oxidative stress and DNA damage in vitro via upregulation of glutathione synthesis. Atherosclerosis, 199 (2), 278287. Retrieved from: https://doi.org/10.1016/j.atherosclerosis.2007.11.016

19. Shevchuk, O.O. (2015). Influence of carbon enterosorbent and granulocyte colony stimulating factor on prooxidant-antioxidant homeostasis in melphalan use. Pharmacology and Drug Toxicology, (4-5), 97-102 [in Ukrainian].

20. Sakhno, L.A., Yurchenko, O.V., Maslenniy, V.N., Bardakhivskaya, K.I., Nikolaeva, V.V., Ivanyuk, A.A., ... Nikolaev, V.G. (2013). Enterosorption as a method to decrease the systemic toxicity of cisplatin. Experimental Oncology, 35 (1), 45-52. Retrieved from: http://dspace. nbuv.gov.ua/handle/123456789/139113
21. Stefanov, O.V. (2001). Preclinical studies of drugs: methodical instructions (O. V. Stefanov, Ed.). Kyiv: Avicenna. Retrieved from: https://www.twirpx.com/ file/537410/ [in Ukrainian].

22. Schwenkglenks, M., Pettengell, R., Jackisch, C., Paridaens, R., Constenla, M., Bosly, A., ... Leonard, R. (2011). Risk factors for chemotherapy-induced neutropenia occurrence in breast cancer patients: data from the INC-EU Prospective Observational European Neutropenia Study. Supportive Care in Cancer: Official Journal of the Multinational Association of Supportive Care in Cancer, 19(4), 483-490. Retrieved from: https://doi.org/10.1007/ s00520-010-0840-y

23. Shevchuk, O.O., Posokhova, K.A., Sidorenko, A.S., Bardakhivska, K.I., Maslenny, V.M., Yushko, L.A., ... Nikolaev, V.G. (2014). The influence of enterosorption on some haematological and biochemical indices of the normal rats after single injection of melphalan. Experimental Oncology, 36 (2), 94-100.

24. Bruslova, K.M. (2013). Tevagrastim use in children with acute leukemia. Onkologia, 15 (1), 51-54 [in Ukrainian].

25. Kriachok, I.A., \& Tytorenko, I.B. (2015). Granulocyte colony stimulating factors at anti-cancer therapy. Klinicheskaia Onkologia, 19 (3), 64-68 [in Ukrainian].

26. Sanganalmath, S.K., Abdel-Latif, A., Bolli, R., Xuan, Y.-T., \& Dawn, B. (2011). Hematopoietic cytokines for cardiac repair: mobilization of bone marrow cells and beyond. Basic Research in Cardiology, 106 (5), 709-733. Retrieved from: https://doi.org/10.1007/s00395-0110183-y.

27. Xu, W.H., Son, J., Wang, Y., Yong, X.R., Lian, Q., Majiti, W., ... Zhong, C. H. (2006). Granulocyte colonystimulating factor reduces cardiomyocyte apoptosis and improves cardiac function in adriamycin-induced cardiomyopathy in rats. Cardiovascular Drugs and Therapy, 20 (2), 85-91. Retrieved from: https://doi.org/10.1007/ s10557-006-7652-9.

28. Andreeva, L.I., Kozhemyakin, L.A., \& Kishkun, A.A. (1988). Modification of the method of identification of lipid peroxides in test with thiobarbituric acid. Laboratornoe Delo, (11), 41-43 [in Russian].

29. Chevari, S., Chaba, I., \& Sekei, I. (1985). Role of super oxide dismutase in oxidative processes of the cell and method of its identification in biological materials. Laboratornoe Delo, (11), 678-681 [in Russian].

30. Koroliuk, M.A., Ivanova, L.K., Maiorova, I.G., \& Tokareva, V.A. (1988). Method of Identification of catalase's activity. Klinicheskaia Laboratornaia Diagnostika, (4), 44-47 [in Russian].

31. Ellman, G.L. (1959). Tissue sulfhydryl groups. Archives of Biochemistry and Biophysics, 82 (1), 70-77.

32. Stocks, J., Gutteridge, J.M.C., Sharp, R.J., \& Dormansy, T.L. (1974). Assay using brain homogenate for measuring the antioxidant activity of biological fluids. Clin. Sci. Mol. Med., 47, 215-222. Retrieved from: https:// pdfs.semanticscholar.org/ 95 e $8 /$ aa 1 b 7 e e7018cdaf8511f0512d0117b10bf1a.pdf.

33. Grek, O.R., Mishenina, S.V., \& Pupyshev, A.B. (2002). Protective effect of enterosgel on rat liver lysosomes during cytostatic treatment. Bulletin of Experimental Biology and Medicine, 134 (10), 413-417 [in Russian].

34. Ponomoriova, O.V., Pivniuk, V.M., Nosko, M.M., Sakhno, L.O., Dekhtiar, T.V., Nikolaev, V.G., \& Che- 
khun, V.F. (2008). Prophylaxis by carbon enterosorbent of acute and delayed emetogenic toxicity of chemotherapeutic treatment of oncological patients. Onkologia, 10 (3), 370-373. Retrieved from http://dspace.nbuv.gov.ua/ handle/123456789/11944 [in Ukrainian].

35. Posokhova, K.A., \& Shevchuk, O.O. (2010). Correction of hepatotoxic action of antiretroviral drugs by glutargin and enterosgel. Ukrainian Journal of Clinical and Laboratory Medicine, 5 (4), 130-133 [in Ukrainian].

36. Nikolaev, V.G., Klishch, I.M., Zhulkevych, I.V., Oleshchuk, O.M., Nikolaeva, V.V., \& Shevchuk, O.O (2009). The use of Enterosgel for prophylaxis of oxidative stress in acute hemorrhage. Bulletin of Scientific Research (Visnyk Naukovykh Doslidzhen), (1), 72-74 [in Ukrainian].

37. Lushchak, V.I. (2014). Classification of oxidative stress based on its intensity. EXCLI Journal, 13, 922-937. Retrieved from: https://doi.org/10.17877/DE290R-7035

38. Khaper, N, Kaur, K., Li, T., Farahmand, F., \& Singal, P.K. (2003). Antioxidant enzyme gene expression in congestive heart failure following myocardial infarction. Molecular and Cellular Biochemistry, 251(1-2), 9-15. Retrieved from: https://doi.org/10.1023/A:1025448908694

39. Khaper, Neelam, \& Singal, P.K. (1997). Effects of afterload-reducing drugs on pathogenesis of antioxidant changes and congestive heart failure in rats. Journal of the American College of Cardiology, 29 (4), 856-861. Retrieved from: https://doi.org/10.1016/S07351097(96)00574-8
40. Rashikh, A., Abul Kalam Najmi, Akhtar, M., Mahmood, D., Pillai, K.K., \& Ahmad, S.J. (2011). Protective effects of aliskiren in doxorubicin-induced acute cardiomyopathy in rats. Human and Experimental Toxicology, 30 (2), 102-109. Retrieved from: https://doi. org/10.1177/0960327110369819

41. Golubtsov, O.Yu., Tyrenko, V.V., Poliakov, A.S., Makiev, R.G., \& Shakhnovich, P.G. (2017). Prospects of antioxidants use for prophylaxis of cardiotoxicity, induced by anthracycline antibiotics. Bulletin of Pirogov National Medical \& Surgical Center, (2), 121-125 [in Russian].

42. Kovalenko, V.N., Kalinkina, N.V., \& Vatutin, N.T. (2002). Damage of the heart by cytostatics. Donetsk: UkrNTEK [in Russian].

43. Mamchur, V.I., Shalamai, A.S., Starchenko, M.G., Kravchenko, K.O., \& Chernov, E.O. (2005). New drugs of quercetin for prevention of doxorubicin-induced cardiomyopathy in experiment. Medychni Perspektyvy, $X$ (4), 4-8. Retrieved from: https://cyberleninka.ru/article/v/ vikoristannya-novih-likarskih-form-kvertsetinu-dlya-profilaktiki-doksorubitsinovoyi-kardiomiopatiyi-v-eksperimenti [in Ukrainian].

44. Yan, T.D. (2010). A pharmacological review on intraperitoneal chemotherapy for peritoneal malignancy. World Journal of Gastrointestinal Oncology, 2 (2), 109. Retrieved from: https://doi.org/10.4251/wjgo.v2.i2.109

45. Nagai, K., Nogami, S., Egusa, H., \& Konishi, H. (2014). Pharmacokinetic evaluation of intraperitoneal doxorubicin in rats. Pharmazie, 69, 125-127. Retrieved from: https://doi.org/10.1691/ph.2014.3754

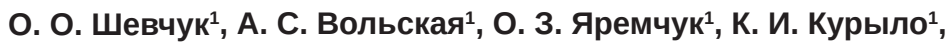

К. И. Бардахивская ${ }^{2}$, В. Г. Николаев ${ }^{2}$, Е. А. Посохова ${ }^{1}$ ТЕРНОПОЛЬСКИЙ НАЦИОНАЛЬНЫЙ МЕДИЦИНСКИЙ УНИВЕРСИТЕТ ИМЕНИ И. Я. ГОРБАЧЕВСКОГО МОЗ УКРАИНЫ ${ }^{1}$ ИНСТИТУТ ЭКСПЕРИМЕНТАЛЬНОЙ ПАТОЛОГИИ, ОНКОЛОГИИ И РАДИОБИОЛОГИИ ИМЕНИ Р. Е. КАВЕЦКОГО НАН УКРАИНЫ ${ }^{2}$, КИЕВ

\section{ПРООКСИДАНТНО-АНТИОКСИДАНТНЫЙ БАЛАНС В ОРГАНИЗМЕ КРЫС НА ФОНЕ СУБХРОНИЧЕСКОЙ ДОКСОРУБИЦИНОВОЙ ТОКСИЧНОСТИ И ПРИМЕНЕНИЯ ЭНТЕРОСОРБЦИИ И ФИЛГРАСТИМА} (обзор литературы и результаты собственных исследований)

\section{Резюме}

Вступление. Антрациклиновые антибиотики остаются одними из наиболее востребованных противоопухолевых лекарственных средств благодаря высокой цитотоксичной и противоопухолевой активности. Однако на протяжении многих лет нерешенной проблемой остается их кардиотоксичность и способность вызывать необратимое повреждение миокарда с развитием застойной сердечной недостаточности с высокой летальностью.

Цель иссследования - изучить влияние энтеральной сорбционной терапии и препарата гранулоцитарного колониестимулирующего фрактора на показатели прооксидантно-антиоксидантного равновесия у крыс на модели субхронической токсичности доксорубицина.

Методы исследования. Эксперименты проводили на половозрелых крысах-самцах, у которых моделировали субхроническую доксорубициновую токсичность, а для коррекции применяли гранулированный углеродный энтеросорбент C2 самостоятельно и в комбинации с фрилграстимом. Исследовали показатели ТБК-активных продуктов, активность каталазы, супероксиддисмутазы, содержание восстанов- 
ленного глутатиона в тканях сердца, печени и сыворотке крови, общую антиокислительную активность сыворотки крови.

Результаты и обсуждение. На фоне субхронической доксорубициновой токсичности у крыс выявлено нарушение прооксидантно-антиоксидантного баланса, которое проявлялось возрастанием уровня ТБК-активных продуктов в сыворотке крови (в 2,07 раза), тканях сердца (в 2,3 раза) и печени (в 1,7 раза). В то же время наблюдали угнетение звеньев эндогенной антиоксидантной защиты со снижением активности каталазы, супероксиддисмутазы, содержания восстановленного глутатиона во всех исследуемых биологических средах, которое было максимальным преимущественно в тканях сердца. Применение энтеросорбента C2 способствовало восстановлению окислительно-восстановительного баланса. Дополнительное использование фрилграстима продемонстрировало дальнейшее улучшение исследуемых показателей и статистически достоверно превосходило моноприменение энтеросорбента по уровню ТБК-активных продуктов в тканях сердца, активности каталазы в тканях сердца и сыворотке крови.

Вывод. Полученные результаты - основа для дальнейшего изучения возможностей комбинированного применения энтеральной сорбционной терапии и фрилграстима с целью уменьщения побочных эфроректов антрациклиновых антибиотиков.

КЛЮЧЕВЫЕ СЛОВА: прооксидантно-антиоксидантный баланс; доксорубицин; энтеросорбция; филграстим; крысы.

O. O. Shevchuk ${ }^{1}$, A. S. Volska ${ }^{1}$, O. Z. Yaremchuk ${ }^{1}$, Kh. I. Kurylo ${ }^{1}$, K. I. Bardakhivska², V. G. Nikolaev ${ }^{2}$, K. A. Posokhova ${ }^{1}$ I. HORBACHEVSKY TERNOPIL NATIONAL MEDICAL UNIVERSITY ${ }^{1}$ R. KAVETSKY INSTITUTE OF EXPERIMENTAL PATHOLOGY, ONCOLOGY AND RADIOBIOLOGY OF THE NATIONAL ACADEMY OF SCIENCE OF UKRAINE ${ }^{2}$, KYIV

\section{PROOXIDANT-ANTIOXIDANT BALANCE IN THE BODY OF RATS IN SUBCHRONIC DOXORUBICIN TOXICITY AND ENTEROSORPTION AND FILGRASTIM USE (LITERATURE REVIEW AND RESEARCH RESULTS)}

\section{Summary}

Introduction. Anthracyclines are among the most effective anti-cancer and cytotoxic drugs along years. Unfortunately, over the years, its cardiotoxic effects and irreversible heart damage with followed congestive heart failure is still unresolved problem for today.

The aim of the study - to estimate the effects of enteral sorption therapy and biosimilar of granulocyte colony stimulating factor (G-CSF) on the oxidative stress indices in Subchronic doxorubicin toxicity.

Research Methods. Subchronic doxorubicin toxicity was modeled on rats, for correction carbon granular oral adsorbent $C 1$ was used alone and in combination with Filgrastim. The indices of oxidative stress development were studied, namely TBA-products, activity of SOD and catalase. Level of reduced glutathione in heart and liver tissues and in blood serum, as well as total antioxidant activity of the blood.

Results and Discussion. Prooxidant-antioxidant imbalance was detected in subchronic doxorubicin toxicity with increased levels of TBA-products in blood serum (in 2.07 times), in the heart tissues (in 2.3 times) and on the liver (in 1.7 times). At the same time, we observed inhibition of endogenic antioxidant defense with suppressed activity of catalase and SOD, and lower level of reduced glutathione, which was expressed the most in the heart tissue predominantly. Enterosorption with C2 promoted a prooxidant-antioxidant balance restore. Combination of C2 with Filgrastim demonstrated the tendency to positive progress of all indices and was significantly better (compared to C2 use only) for the indices of TBA-products catalase activity in the heart tissues and catalase activity in blood serum.

Conclusion. The results of our study are a substantiation for deeper research of capability of enterosorption and G-CSF Filgrastim to ameliorate the anthracyclines side effects.

KEY WORDS: prooxidant-antioxidant balance; doxorubicin; enterosorption; filgrastim; rats.

Адреса для листування: О. О. Шевчук, Тернопільський національний медичний університет імені І. Я. Горбачевського МОЗ України, майдан Волі, 1, Тернопіль, 46001, Україна, e-mail: shevchukoo@tdmu.edu.ua. 